\title{
The impact of COVID-19 pandemic on reproductive intentions among the Polish population
}

\author{
Agnieszka Sienicka ${ }^{1}$, Agata Pisula ${ }^{1}$, Katarzyna K. Pawlik ${ }^{1}$, \\ Joanna Kacperczyk-Bartnik ${ }^{2} \mathbb{D}$, Pawel Bartnik ${ }^{2} \mathbb{D}$, \\ Agnieszka Dobrowolska-Redo² ${ }^{2}$, Ewa Romejko-Wolniewicz² \\ 'Students' Scientific Group affiliated to II Department of Obstetrics and Gynecology, Medical University of Warsaw, Poland \\ $2 / l$ Department of Obstetrics and Gynecology, Medical University of Warsaw, Poland
}

\begin{abstract}
Objectives: The study was conducted in order to determine the impact of the COVID-19 pandemic on the fertility intentions among the Polish population.

Material and methods: A cross-sectional, questionnaire-based online study was carried out among Polish adults in order to determine the impact of the COVID-19 pandemic on the reproductive plans of the Polish society. A total of 984 participants correctly completed the survey.

Results: The pandemic has affected the reproductive intentions of $22 \%(n=216)$ of the respondents, most of them want to have a child later than they previously planned (74.1\%). The relationship between the change in reproductive intentions and the concerns about the pandemic was found. Most of those who changed their plans were afraid that the access to prenatal care and delivery services could be limited (86.6\%) or were afraid about giving birth at the hospital (81\%). More than half (51.9\%) of those who changed reproductive plans were afraid of losing their income and $40.3 \%$ had already experienced a decrease in their income. The change in partner's emotional relationships was also observed. More than half of respondents $(56.7 \%)$ admitted that during the pandemic they had developed a deeper emotional relationship with their partners or felt more emotionally supported (56.6\%). Most participants responded that the frequency of their sexual intercourses was not affected (66.7\%) and that they had not experienced limited access to contraceptives (95.1\%) during the pandemic. Conclusions: The COVID-19 pandemic has affected Polish people's reproductive intentions. Concerns related to healthcare access and the economic difficulties have the most significant impact.
\end{abstract}

Key words: COVID-19; pandemic; reproductive health; reproduction

\section{INTRODUCTION}

The coronavirus disease 2019 (COVID-19) is caused by Severe Acute Respiratory Syndrome Coronavirus 2 (SARS-CoV-2). The virus belongs to the coronaviruses family that primarily targets the human respiratory system. On 11 March 2020, the World Health Organization (WHO) declared COVID-19 as a pandemic [1]. According to the WHO updates on the present epidemiological situation there have already been a hundred and a half million confirmed cases of COVID-19, including more than 3 million deaths. In Poland, the situation is also severe, with nearly 3 million confirmed cases and tens of thousands of deaths [2]. The pandemic has had a big impact on the social, political, economic, and psychological aspects of human lives [3]. People must face a completely new situation. Lockdowns, quarantines and social distancing have entered everyday language. People all over the world began working remotely from home, and many even lost their jobs [4]. Children had to get used to remote learning and home education [5]. Another aspect of the pandemic is that the healthcare system is struggling with problems and overloading $[6,7]$. Access to healthcare is more difficult. We conducted a cross-sectional online survey to collect information on how pandemic affects the reproductive plans in various socioeconomic groups.

\section{Objectives}

The study was conducted in order to determine the reproductive intentions among the Polish society during COVID-19 pandemic.

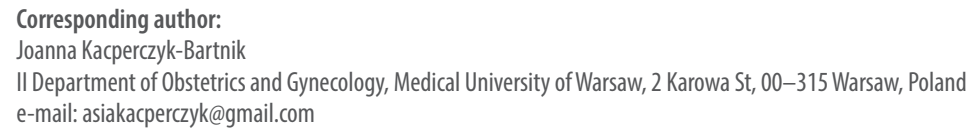




\section{MATERIAL AND METHODS}

A cross-sectional, questionnaire-based study was carried out among adult Polish, men and women, in order to determine the reproductive plans of the Polish society during COVID-19 pandemic. The self-administered survey was created online using the survey administration software Google Forms and distributed among 87 Polish Facebook groups. The data were collected for approximately one month, from 8 December 2020 to 6 January 2021. At the beginning of the questionnaire, all potential participants were informed about the survey, its objectives, the way and extent of use of the received data, and the voluntary nature of participation. Anonymity and confidentiality were ensured. The recruitment criteria were Polish people aged between 18 and 49 years. As the exclusion criteria we established: homosexual orientation and people who had not initiated sexual intercourse. The questionnaire was divided into several sections. Basic sociodemographic and economic data as well as information about the offspring and reproductive plans were collected. Participants were also asked about their emotional relationship with their partners and their sexual activity during the pandemic. Emphasis was placed on obtaining as much detailed information as possible about changes in the life situation of the participants as well as changes and concerns in their procreation plans due to the pandemic. With the purpose of achieving a $99 \%$ confidence level and a $5 \%$ margin of error, the sample size of 666 participants was calculated. The obtained data were analysed using descriptive statistics and the Chi-Square test to assess the significance of the responses. Statistical significance was detected by a $p$ value $<0.05$.

\section{RESULTS}

The study included a total of 984 respondents: 887 women (90.1\%), 95 men (9.7\%) and 2 non-binary people (0.2\%). The mean age was 29.2 (SD 5.8) years (range 18 to 49 years). The baseline sociodemographic features are described in Table 1.

Table 1. Sociodemographic characteristics

\begin{tabular}{|l|l|l|l|}
\hline $\begin{array}{l}\text { Category } \\
(\mathbf{n = 9 8 4 )}\end{array}$ & Variables & Frequency & Percentage \\
\hline \multirow{2}{*}{ Gender } & Female & 887 & $90.1 \%$ \\
\hline & Male & 95 & $9.7 \%$ \\
\hline & Non-binary & 2 & $0.2 \%$ \\
\hline Age & $18-25$ & 320 & $32.5 \%$ \\
\hline & $26-30$ & 276 & $28.1 \%$ \\
\hline $31-35$ & 238 & $24.2 \%$ \\
\hline & $36-40$ & 115 & $11.7 \%$ \\
\hline $41-49$ & 35 & $3.6 \%$ \\
\hline
\end{tabular}

\begin{tabular}{|c|c|c|c|}
\hline $\begin{array}{l}\text { Category } \\
(n=984)\end{array}$ & Variables & Frequency & Percentage \\
\hline \multirow{2}{*}{ Religion } & Believer & 689 & $70 \%$ \\
\hline & Non-believer & 295 & $30 \%$ \\
\hline \multirow{5}{*}{ Education } & Primary & 6 & $0.6 \%$ \\
\hline & Vocational & 13 & $1.3 \%$ \\
\hline & Secondary & 137 & $13.9 \%$ \\
\hline & Studying & 177 & $18 \%$ \\
\hline & Higher & 651 & $66.2 \%$ \\
\hline \multirow{4}{*}{ Employment } & Employed & 644 & $65.4 \%$ \\
\hline & Unemployed & 157 & $16 \%$ \\
\hline & Self-employed & 90 & $9.1 \%$ \\
\hline & Others & 93 & $9.5 \%$ \\
\hline \multirow{6}{*}{$\begin{array}{l}\text { Average income } \\
\text { per household } \\
\text { member }\end{array}$} & $<1000$ PLN & 62 & $6.3 \%$ \\
\hline & $1000-2000$ PLN & 239 & $24.3 \%$ \\
\hline & 2000-3000 PLN & 273 & $27.7 \%$ \\
\hline & $3000-4000$ PLN & 173 & $17.6 \%$ \\
\hline & $4000-5000$ PLN & 95 & $9.7 \%$ \\
\hline & $>5000$ PLN & 142 & $14.4 \%$ \\
\hline \multirow{5}{*}{$\begin{array}{l}\text { Place of } \\
\text { residence }\end{array}$} & Countryside & 202 & $20.5 \%$ \\
\hline & $\begin{array}{l}\text { Small village } \\
\text { ( }<50 \text { k residents) }\end{array}$ & 169 & $17.2 \%$ \\
\hline & $\begin{array}{l}\text { Town }(50 \mathrm{k}-100 \mathrm{k} \\
\text { residents) }\end{array}$ & 115 & $11.7 \%$ \\
\hline & City (100 k-500 k) & 142 & $14.4 \%$ \\
\hline & City (> 500 k) & 356 & $36.2 \%$ \\
\hline \multirow{4}{*}{$\begin{array}{l}\text { Current } \\
\text { relationship } \\
\text { status }\end{array}$} & Single & 65 & $6.6 \%$ \\
\hline & $\begin{array}{l}\text { In informal } \\
\text { relationship }\end{array}$ & 340 & $34.6 \%$ \\
\hline & Married & 575 & $58.4 \%$ \\
\hline & Divorced & 4 & $0.4 \%$ \\
\hline \multirow{4}{*}{ Parenting status } & Yes, I have a child & 395 & $40.1 \%$ \\
\hline & $\begin{array}{l}\text { Yes, I am expecting } \\
\text { a baby }\end{array}$ & 71 & $7.2 \%$ \\
\hline & $\begin{array}{l}\text { Yes, I have a child } \\
\text { and I am expecting } \\
\text { a baby }\end{array}$ & 71 & $7.2 \%$ \\
\hline & No & 447 & $45.4 \%$ \\
\hline \multirow{5}{*}{$\begin{array}{l}\text { Number of } \\
\text { pregnancies } \\
\text { (your or your } \\
\text { partner's) }\end{array}$} & 0 & 442 & $44.9 \%$ \\
\hline & 1 & 217 & $22.1 \%$ \\
\hline & 2 & 199 & $20.2 \%$ \\
\hline & 3 & 70 & $7.1 \%$ \\
\hline & $>4$ & 56 & $5.7 \%$ \\
\hline \multirow{5}{*}{$\begin{array}{l}\text { Number of } \\
\text { deliveries }\end{array}$} & 0 & 509 & $51.7 \%$ \\
\hline & 1 & 260 & $26.4 \%$ \\
\hline & 2 & 165 & $16.8 \%$ \\
\hline & 3 & 36 & $3.7 \%$ \\
\hline & $>4$ & 14 & $1.4 \%$ \\
\hline \multirow{2}{*}{$\begin{array}{l}\text { Currently trying } \\
\text { for a baby }\end{array}$} & Yes & 150 & $15.2 \%$ \\
\hline & No & 834 & $84.8 \%$ \\
\hline
\end{tabular}


For 753 (76.5\%) respondents, the pandemic had no impact on their employment. The number of participants who lost their jobs or had to quit their own business ( $n=55,5.6 \%$ ) was similar to those who became employed or started their own business - 53 (5.4\%). Other impacts of the pandemic on their employment were declared by 120 people surveyed (12.2\%). Among those who are currently employed, 181 (18.4\%) work partly remotely and 125 (12.7\%) work fully remotely. Out of the people who have an employed partner $(n=858), 101$ (10.3\%) respondents stated that their partner worked partly remotely and 150 (15.2\%) said that their partner worked currently entirely remotely (Tab. 2). The income per household member decreased in 279 (28.4\%) individuals and increased in 119 (12.1\%). A total of 352 (35.8\%) of the respondents replied that they were afraid of losing their income due to the pandemic.

More than half of the respondents $(n=606,61.6 \%)$ declared that before the pandemic they had planned on having children. Out of that group, 386 (39.2\%) wanted to have children in the nearest future and 220 (22.4\%) were planning on having children in the distant future. The pandemic has affected the reproductive intentions of $22 \%(n=216)$ of the respondents. As shown in Table 3. Amongst respondents who declared that pandemic has changed their reproductive intentions, most want to have a child later than they

\begin{tabular}{|c|c|c|}
\hline Category n = 984 & Frequency & Percentage \\
\hline $\begin{array}{l}\text { Lost their jobs or had to quit their own } \\
\text { business }\end{array}$ & 55 & $5.6 \%$ \\
\hline $\begin{array}{l}\text { Work remotely or partly remotely } \\
\text { because of pandemic }\end{array}$ & 306 & $31.1 \%$ \\
\hline $\begin{array}{l}\text { Their partner works remotely or partly } \\
\text { remotely because of the pandemic }\end{array}$ & 251 & $25.5 \%$ \\
\hline $\begin{array}{l}\text { Their income decreased because of the } \\
\text { pandemic }\end{array}$ & 279 & $28.4 \%$ \\
\hline
\end{tabular}

\begin{tabular}{|c|c|c|}
\hline Category $n=216$ & Frequency & Percentage \\
\hline $\begin{array}{l}\text { Want to have a child later than they } \\
\text { initially planned }\end{array}$ & 160 & $74.1 \%$ \\
\hline $\begin{array}{l}\text { Do not want to have as many children } \\
\text { as they initially planned }\end{array}$ & 56 & $25.9 \%$ \\
\hline Decided not to have children & 40 & $18.5 \%$ \\
\hline $\begin{array}{l}\text { Want to have a child sooner than they } \\
\text { initially planned }\end{array}$ & 20 & $9.3 \%$ \\
\hline $\begin{array}{l}\text { Revealed a desire for parenthood } \\
\text { during pandemic }\end{array}$ & 7 & $3.2 \%$ \\
\hline $\begin{array}{l}\text { Want to have more children than they } \\
\text { initially planned }\end{array}$ & 5 & $2.3 \%$ \\
\hline
\end{tabular}

had previously planned ( $n=160,74.1 \%$ ) or do not want to have as many children as they had initially planned $(n=56$, $25.9 \%)$.

There seems to be a strong relation between the change in reproductive intentions and Polish people's concerns related to the pandemic (Tab. 4). The majority of people whose plans were affected by the pandemic $(n=216)$ were afraid that the access to health services related to pregnancy could be limited ( $n=187,86.5 \%$ ) or were afraid about giving birth at the hospital ( $n=175,81 \%$ ) during the pandemic. Moreover, $76.9 \%$ ( $n=166$ ) of them were concerned about the health of potential offspring due to COVID-19. More than half ( $n=112,51.9 \%$ ) of those who changed reproductive plans were afraid of losing their income and $40.3 \%$ $(n=87)$ had already experienced a decrease in their income, all due to the pandemic. No significant relationship between reproductive intentions and having COVID-19, having lost loved ones due to COVID-19 or being quarantined was observed. In terms of level of education, average income per household, and place of residence, there was no significant association between the affected and unaffected groups (Tab. 5). Furthermore, out of all the respondents who participated in the survey $69.3 \%(n=682)$ experienced difficulties in accessing a doctor or other medical service and more than half ( $\mathrm{n}=550,55.9 \%$ ) were afraid of using health care facilities during the COVID-19 pandemic.

The association between the pandemic and emotional relations between partners was also observed. Eight hundred eighty-seven (90.1\%) participants had been in a relationship before the outbreak and were in the same relationship during the pandemic. More than half of them ( $n=503,56.7 \%)$ admitted that they had developed a deeper emotional relationship with their partners during the pandemic. Five hundred two (56.6\%) respondents felt more emotionally supported by their partners and 433 (48.8\%) indicated to be more affectionate towards each other. The majority $(n=569,64.1 \%)$ admitted that they had spent more time with their partners after the outbreak. Nevertheless, they had not argued more often. No changes in the arguments' frequency were confirmed by $47.9 \%(n=425)$ participants. Table 6 presents the association between changes in emotional relationships and modifications in the reproductive plans of Polish people. Time spent together with the partner did not have any significant impact on changes in the reproductive plans.

During the pandemic, 32 (3.3\%) participants ended their relationship, $65.6 \%(n=21)$ of whom believe that the separation had been or could have been caused by the outbreak.

Out of all respondents, $893(90.8 \%)$ indicated being sexually active. The majority $(66.7 \%, n=656)$ responded that the pandemic had not affected the frequency of their sexual activity, in $19.6 \%(n=193)$ the frequency of their 
Table 4. Association between factors related to the pandemic and change in reproductive intentions

\begin{tabular}{|c|c|c|c|c|}
\hline Category n = 984 & Variable & Affected n (\%) & Unaffected $n(\%)$ & p value \\
\hline \multirow{3}{*}{ Income change } & Increased & $21(17.6 \%)$ & $98(82.4 \%)$ & 0.000061 \\
\hline & Decreased & $87(31.2 \%)$ & $192(68.8 \%)$ & \\
\hline & Has not changed & $108(18.4 \%)$ & $478(81.6 \%)$ & \\
\hline \multirow{2}{*}{$\begin{array}{l}\text { Concerned about losing income due to the } \\
\text { COVID-19 pandemic }\end{array}$} & Yes & $112(31.8 \%)$ & $240(68.2 \%)$ & $<0.00001$ \\
\hline & No & $104(16.5 \%)$ & $528(83.5 \%)$ & \\
\hline \multirow{2}{*}{ Having COVID-19 } & Yes & $42(25.0 \%)$ & $126(75.0 \%)$ & \multirow{2}{*}{ not significant at $p<0.05$} \\
\hline & No & $174(21.3 \%)$ & $642(78.7 \%)$ & \\
\hline \multirow{2}{*}{ Being quarantined } & Yes & $59(25.3 \%)$ & $174(74.7 \%)$ & \multirow{2}{*}{ not significant at $p<0.05$} \\
\hline & No & $157(20.9 \%)$ & $594(79.1 \%)$ & \\
\hline \multirow{2}{*}{$\begin{array}{l}\text { Experienced separation from your partner due to } \\
\text { the COVID-19 pandemic }\end{array}$} & Yes & $55(28.4 \%)$ & $139(71.6 \%)$ & \multirow[t]{2}{*}{0.016249} \\
\hline & No & $161(20.4 \%)$ & $629(79.6 \%)$ & \\
\hline \multirow{2}{*}{$\begin{array}{l}\text { Lost one of your loved ones due to the } \\
\text { COVID-19 pandemic }\end{array}$} & Yes & $22(31.0 \%)$ & $49(69.0 \%)$ & \multirow{2}{*}{ not significant at $p<0.05$} \\
\hline & No & $194(21.2 \%)$ & $719(78.8 \%)$ & \\
\hline \multirow{2}{*}{$\begin{array}{l}\text { Afraid that the access to health services related to } \\
\text { pregnancy could be limited due to pandemic }\end{array}$} & Yes & $187(30.5 \%)$ & $427(69.5 \%)$ & \multirow[t]{2}{*}{$<0.00001$} \\
\hline & No & $29(7.8 \%)$ & $341(92.2 \%)$ & \\
\hline \multirow{2}{*}{ Afraid about giving birth at hospital } & Yes & $175(29.6 \%)$ & $416(70.4 \%)$ & \multirow[t]{2}{*}{$<0.00001$} \\
\hline & No & 41 (10.4\%) & 352 (89.6\%) & \\
\hline \multirow{2}{*}{$\begin{array}{l}\text { Concerned about the health of potential offspring } \\
\text { due to the pandemic }\end{array}$} & Yes & $166(29.8 \%)$ & 391 (70.2\%) & $<0.00001$ \\
\hline & No & 50 (11.7\%) & 377 (88.3\%) & \\
\hline
\end{tabular}

Table 5. Association between socio-economic characteristics of responders and change in reproductive intentions

\begin{tabular}{|c|c|c|c|c|}
\hline Category n = 984 & Variable & Affected n (\%) & Unaffected n (\%) & $p$ value \\
\hline \multirow{5}{*}{ Age } & $18-25$ & $65(20.3 \%)$ & $255(79.7 \%)$ & 0.013275 \\
\hline & $26-30$ & $73(26.4 \%)$ & $203(73.6 \%)$ & \\
\hline & $31-35$ & $58(24.4 \%)$ & $180(75.6 \%)$ & \\
\hline & $36-40$ & $18(15.7 \%)$ & 97 (84.3\%) & \\
\hline & $41-49$ & $2(5.7 \%)$ & $33(94.3 \%)$ & \\
\hline \multirow{5}{*}{ Education } & Primary & $1(16.7 \%)$ & $5(83.3 \%)$ & \multirow{5}{*}{ not significant at $p<0.05$} \\
\hline & Vocational & $2(15.4 \%)$ & $11(84.6 \%)$ & \\
\hline & Secondary & $27(19.7 \%)$ & $110(80.3 \%)$ & \\
\hline & Studying & $36(20.3 \%)$ & $141(79.7 \%)$ & \\
\hline & Higher & $150(23.0 \%)$ & $501(77.0 \%)$ & \\
\hline \multirow{5}{*}{ Place of residence } & Countryside & $42(20.8 \%)$ & $160(79.2 \%)$ & \multirow{5}{*}{ not significant at $p<0.05$} \\
\hline & Small village ( $<50000$ residents) & $36(21.3 \%)$ & $133(78.7 \%)$ & \\
\hline & Town (50 000-100 000 residents) & $26(22.6 \%)$ & $89(77.4 \%)$ & \\
\hline & City $(100000-500000)$ & $22(15.5 \%)$ & $120(84.5 \%)$ & \\
\hline & City $(>500000)$ & $90(25.3 \%)$ & $266(74.7 \%)$ & \\
\hline \multirow{6}{*}{ Average Income per household } & $<1000$ PLN & $12(19.4 \%)$ & $50(80.6 \%)$ & \multirow{6}{*}{ not significant at $p<0.05$} \\
\hline & $1000-2000$ PLN & $50(20.9 \%)$ & $189(79.1 \%)$ & \\
\hline & 2000-3000 PLN & $66(24.2 \%)$ & $207(75.8 \%)$ & \\
\hline & 3000-4000 PLN & $44(25.4 \%)$ & $129(74.6 \%)$ & \\
\hline & 4000-5000 PLN & $15(15.8 \%)$ & $80(84.2 \%)$ & \\
\hline & $>5000$ PLN & $29(20.4 \%)$ & $113(79.6 \%)$ & \\
\hline
\end{tabular}


Table 6. The impact of changes in emotional relations on modifications in reproductive plans

\begin{tabular}{|c|c|c|c|c|}
\hline Category $n=887$ & Variable & Affected n (\%) & Unaffected n (\%) & p value \\
\hline \multirow{3}{*}{ Emotional intimacy } & decreased & 27 (39.1\%) & 42 (60.9\%) & 0.00223 \\
\hline & not changed & 65 (20.6\%) & $250(79.4 \%)$ & \\
\hline & increased & $106(21.1 \%)$ & 397 (78.9\%) & \\
\hline \multirow{3}{*}{ Emotional support } & decreased & $28(44.4 \%)$ & 35 (55.6\%) & 0.000025 \\
\hline & not changed & $58(18.0 \%)$ & $264(82.0 \%)$ & \\
\hline & increased & $112(21.9 \%)$ & 390 (78.1\%) & \\
\hline \multirow{3}{*}{ Display of affection } & decreased & 39 (42.4\%) & $53(57.6 \%)$ & $<0.00001$ \\
\hline & not changed & 70 (19.3\%) & $292(80.7 \%)$ & \\
\hline & increased & $89(20.6 \%)$ & $344(79.4 \%)$ & \\
\hline \multirow{3}{*}{ Time spent together } & decreased & $29(29.0 \%)$ & $71(71.0 \%)$ & \multirow{3}{*}{ not significant at $p<0.05$} \\
\hline & not changed & $43(19.7 \%)$ & $175(80.3 \%)$ & \\
\hline & increased & $126(22.1 \%)$ & 443 (77.9\%) & \\
\hline \multirow{3}{*}{ Incidence of arguments } & decreased & 49 (21.9\%) & $175(78.1 \%)$ & 0.010402 \\
\hline & not changed & $80(18.8 \%)$ & $345(81.2 \%)$ & \\
\hline & increased & 69 (29.0\%) & 169 (71.0\%) & \\
\hline
\end{tabular}

sexual activity decreased and in $13.7 \%(n=135)$ increased. Amongst all sexually active participants $(n=893), 28.9 \%$ $(n=258)$ answered that they did not use any contraception. $41.0 \%(n=366)$ indicated that they or their partner used barrier contraception, $26.2 \%(n=234)$ hormonal contraception, and $6.5 \%(n=58)$ chose other methods. The vast majority $(95.1 \%, n=849)$ admitted that they had not experienced any limited access to contraceptives during pandemic.

\section{DISCUSSION}

The outbreak of coronavirus disease in late December 2019 in China quickly became an emerging situation, rapidly spreading outside China, which in March 2020 was declared as a pandemic by the World Health Organization [1]. This pandemic is having a major impact not only on people's physical health but also on mental and sexual well-being [8, 9]. As far as we are aware, our study is the first to investigate the intentions for parenthood amongst adult Polish people during the COVID-19 outbreak.

Previous studies have shown that Polish people had been worried about the COVID-19 pandemic and that fear of the virus spreading is a significant predictor of emotional distress $[10,11]$. Our study shows that, concerns related to the pandemic are also having an overall impact on Polish people's reproductive plans. People are concerned not only about staying in healthcare facilities but also about the possibility of the limitations in the access to health services related to pregnancy or the health of their offspring. Due to those concerns and worries, people are mostly delaying their reproductive plans or deciding not to have as many children than they initially planned. Similar results were observed in a study conducted in Italy, where $37.3 \%$ of couples who were planning to have a child decided to postpone parenthood during the quarantine [12].

The COVID-19 pandemic is having a major impact on the global economy, so it is not surprising that economic factors are also associated with people's change in reproductive intentions. The decrease in income or the fear of the decrease is affecting Polish people's desire for parenthood. In contrast to the other concerns, this may delay those intentions for much longer because of its consequences in people's material prosperity. Even though, the survey from Italy revealed similar observations [12], this may not be a global trend. The study that was performed to evaluate reproductive intentions among couples in Shanghai under the COVID-19 pandemic, revealed that the decrease in income did not significantly affect the reproductive intention [11].

Interestingly, the pandemic has had a positive impact on emotional relationships between partners due to the overall increase in emotional intimacy, sensitivity and mutual support. People were forced to stay at home, which resulted in spending much more time together every day. As the study shows, these changes in most people's lives have fortunately had a positive influence on their relationships.

On $27^{\text {th }}$ December 2020, vaccination programme against COVID-19 began in Poland [12]. This is an opportunity to end the pandemic, which may hopefully dispel Polish people's concerns and the return of their previous reproductive plans.

\section{CONCLUSIONS}

The COVID-19 pandemic has affected Polish people's reproductive intentions; however, those plans are mostly 
just delayed, not entirely abstained. Concerns related to healthcare access have the strongest association with people's change in reproductive plans. Moreover, the economic difficulties also have a significant influence. Although the COVID-19 pandemic is negatively associated with Polish people's desire to have children, our study shows that it also has a positive impact on emotional relations between partners.

\section{Acknowledgments}

We sincerely thank all the Polish men and women who participated in this survey.

\section{Conflict of interest}

The authors declare no conflict of interest.

\section{REFERENCES}

1. WHO. WHO Director-General's opening remarks at the media briefing on COVID-19 - 11 March 2020. https://www.who. int/director-general/speeches/detail/who-director-general-s-opening-remarks-at-the-media-briefing-on-covid-19---11-march-2020.

2. WHO Coronavirus Disease (COVID-19) Dashboard. COVID 19 Special Issue. 2020; 10(1), doi: 10.46945/bpj.10.1.03.01.

3. Holmes E, O'Connor R, Perry V, et al. Multidisciplinary research priorities for the COVID-19 pandemic: a call for action for mental health science. The Lancet Psychiatry. 2020; 7(6): 547-560, doi: 10.1016/s22150366(20)30168-1.
4. Venkatesh V. Impacts of COVID-19: A research agenda to support people in their fight. Int J Inf Manage. 2020; 55: 102197, doi: 10.1016/j. ijinfomgt.2020.102197, indexed in Pubmed: 32836648.

5. Parczewska T. Difficult situations and ways of coping with them in the experiences of parents homeschooling their children during the COVID-19 pandemic in Poland. Education 3-13. 2020: 1-12, doi: 10.1080/03004279.2020.1812689.

6. Białynicki-Birula R, Siemasz I, Otlewska A, et al. Influence of COVID-19 pandemic on hospitalizations at the tertiary dermatology department in south-west Poland. Dermatol Ther. 2020; 33(4): e13738, doi: 10.1111/dth.13738, indexed in Pubmed: 32478949.

7. Pustułka P, Buler M. Pregnancy and childbirth during the COVID-19 pandemic in Poland: qualitative evidence from expert interviews. , doi: 10.21203/rs.3.rs-48024/v3.

8. Gambin M, Sękowski M, Woźniak-Prus M, et al. Generalized anxiety and depressive symptoms in various age groups during the COVID-19 lockdown in Poland. Specific predictors and differences in symptoms severity. Compr Psychiatry. 2021; 105: 152222, doi: 10.1016/j. comppsych.2020.152222, indexed in Pubmed: 33388494.

9. Gawrych M, Cichoń E, Kiejna A. COVID-19 pandemic fear, life satisfaction and mental health at the initial stage of the pandemic in the largest cities in Poland. Psychol Health Med. 2021; 26(1): 107-113, doi: 10.1080/13548506.2020.1861314, indexed in Pubmed: 33300378.

10. Micelli E, Cito G, Cocci A, et al. Desire for parenthood at the time of COVID-19 pandemic: an insight into the Italian situation. J Psychosom Obstet Gynaecol. 2020; 41(3): 183-190, doi: 10.1080/0167482X.2020.1759545, indexed in Pubmed: 32379999.

11. Zhu C, Wu J, Liang Y, et al. Fertility intentions among couples in Shanghai under COVID-19: A cross-sectional study. Int J Gynaecol Obstet. 2020; 151(3): 399-406, doi: 10.1002/ijgo.13366, indexed in Pubmed: 32880942.

12. Polish Goverment. W Polsce ruszyły szczepienia przeciw COVID-19 - to historyczny moment. https://www.gov.pl/web/szczepimysie/w-polsce-ruszyly-szczepienia-przeciw-covid-19--to-historyczny-moment. 